that there is no deviation from eqn. 5 even at this relatively high concentration.

The financial support of the Swedish Natural Science Research Council (NFR) is gratefully acknowledged. Our sincere thanks are due to Ewert Ingemansson for valuable help and generous support both economically and otherwise when assembling the automatic titration equipment. Derek Lewis kindly revised the English of the text.

1. Chuchani, G., Hernandez, J. A. and Zabicky, J. Nature 207 (1965) 1385.

2. Biedermann, G. and Wallin, T. To bs published.

3. Ciavatta, L. Arkiv Kemi 20 (1963) 417.

4. Gran, G. Analyst 77 (1952) 661 .

5. Ingri, N. and Sillén, L. G. Arkiv Kemi 23 (1964) 97.

6. Perrin, D. D. Dissociation constants of organic bases in aqueous solution, Butterworths, London 1965 , p. 82.

7. Gillois, M. and Rumpf, P. Bull. Soc. Chim. France 1954112.

8. Kuhn, R. and Wasserman, A. Helv. Chim. Acta 11 (1928) 3.

9. Eggers, J., Heckelmann, H., Lohmer, K. and Posse, R. Mitt. Forschungslab. Agfa Leverkusen-M ïnchen 1 (1955) 95; Chem. Abstr. 50 (1956) 6982c.

10. Vandenbelt, J. M., Henrich, C. and Vanden Berg, S. G. Anal. Chem. 26 (1954) 726.

11. Parke, T. V. and Davis, W. W. Anal. Chem. 26 (1954) 642.

12. Fieser, L. F. J. Am. Chem. Soc. 52 (1930) 4915.

13. Veley, V. H. J. Chem. Soc. 93 (1908) 2122.

14. Robinson, R. A. and Stokes, R. H. Electrolyte Solutions, Butterworths, London 1959 , p. 544.

15. von Bandrowski, E. Sitzber. Akad. Wiss. Wien, Abth. 2B (1889) 112.

Received January 15, 1970.

\section{Chemical Studies on Lichens}

\section{8. * The Pigments of Some Foliicolous Lichens}

JOHAN SANTESSON

\author{
Organic Department, Institute of Chemistry, \\ University of Uppsala, Box 531, \\ S.751 21 Uppsala 1, Sweden
}

$\mathrm{N}$ ine species of obligately foliicolous lichens have been studied with regard to their content of coloured secondary metabolic products. Three anthraquinones, three pulvinic acid derivatives, three chlorinated xanthones, and usnic acid were identified by lichen mass spectrometry and thin layer co-chromatography.

The secondary metabolic products of obligately foliicolous lichens (i.e. lichens only occurring on living leaves) ${ }^{1}$ are virtually unknown. Only one substantiated report on their constituents has appeared in the literature: the occurrence of $2,5,7$. trichloronorlichexanthone in Sporopodium phyllocharis (Mont.) Mass. and of 3-O. methyl-2,5,7-trichloronorlichexanthone in $S$. phyllocharis var. flavescens R. Sant. ${ }^{2}$

By means of lichen mass spectrometry (LMS) ${ }^{3}$ and instant thin layer co-chromatography (ITLC) the pigments of nine foliicolous lichens have been studied. All investigated species belong to the family Lecideaceae.

The impossibility of obtaining more than a few milligrammes of lichen material (in advantageous cases!) has precluded isolation of the substances present and has<smiles>[R20]c1cc2c(c(O)c1[R])C(=O)c1c(O)cc(C)cc1C2=O</smiles>

* Part 27: Persson, B. and Santesson, J. Acta Chem. Scand. 24 (1970) 345. 
made it necessary to rely upon LMS and ITLC for the identifications. Both methods have been used in all cases.

Byssoloma tricholomum (Mont.) Zahlbr. em. R. Sant. was found to contain the closely related anthraquinones emodin (I), 7-chloroemodin (II), and fragilin (III). IIII are rather common within the family Teloschistaceae ${ }^{5,8}$ and scattered occurrences in lichens belonging to other families have also been reported. ${ }^{3,7} \rightarrow$ It is significant that no traces of parietin (IV) could be found in $B$. tricholomum. A joint occurrence of $I-I V$ has never been reported from lichens outside Teloschistaceae.<smiles>O=C1OC2=C(c3ccccc3)C(=O)OC2=C1c1ccccc1</smiles>

$\mathbf{Y}$<smiles>CC(=O)/C(=C1/OC(=O)C(c2ccccc2)=C1O)c1ccccc1</smiles>

II

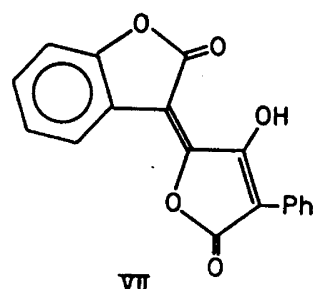

In Sporopodium leprieurii Mont. var. citrinum (Zahlbr.) R. Sant. and in $S$. xantholeucum (Müll. Arg.) Zahlbr. the presence of the pulvinic acid derivatives pulvinic dilactone (V) and vulpinic acid (VI) could be demonstrated. The latter species was also found to contain calycin (VII). These compounds are not uncommon in lichens (for their distribution see Culberson $\left.{ }^{10}\right)$. It should be noted that typical $S$. leprieurii does not contain any pulvinic acid derivatives. ${ }^{\circ}$

Five Lopadium species have been studied. L. foliicola (Fée) R. Sant., L. fuscum Müll. Arg., $L$. nymanii R. Sant., and $L$. phyllogenum (Müll. Arg.) Zahlbr. were found to contain 2,7-dichlorolichexanthone
(VIII), previously known only from Buellia and Pertusaria spp. ${ }^{2,11}$ The same xanthone is also present in some corticolous Lopadium spp." It should be noted that the four foliicolous Lopadium spp. containing VIII all belong to the $L$. fuscum group. ${ }^{1}$<smiles>[R20]c1cc2oc3c([R2])c([R2])c(Cl)c(O)c3c(=O)c2c(C)c1Cl</smiles>

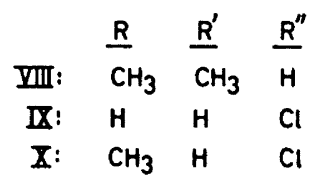

In L. newtonianum (Henriques) R. Sant., the presence of usnic acid was demonstrated. Usnic acid is very common in lichens.

Finally, Tapellaria epiphylla (Müll. Arg.) R. Sant. was shown to contain the chlorinated xanthones arthothelin (IX) and thuringione $(X)$. IX is fairly common in lichens, ${ }^{2}$ while $X$ has been found only in one Lecanora sp.," one Buellia sp.," and one Lecidea sp..$^{12}$

Experimental. The lichen mass spectra were recorded according to Ref. 3, using an LKB 9000 gas chromatograph - mass spectrometer, equipped with a direct inlet system. TLC identifications were made by co-chromatography with authentic samples on Eastman "Chromagram" plates (6060, silica gel), using solvent systems previously described.4,11,13

The lichen material. Voucher specimens are to be found in the herbarium of Uppsala Botanical Museum (UPS). Byssoloma tricholomum: from Cuba, unknown year of collection, reference designation Wright, Lich. Cubae II, 200. Sporopodium leprieurii var. citrinum: China, 1916, Handel-Mazzetti 9866 (isotype). S. xantholeucum: New Guinea, 1929, Herre. Lopadium foliicola: Brazil, 1892, Malme 376 a. L. fuscum: New Guinea, 1940, Clemens. $L$. nymanii: 'Java, 1897, Nyman E I 11 a (holotype). L. phyllogenum: Brazil, 1894, Malme 2398. L. newtonianum: São Thomé, 1888, Newton (isotype). Tapellaria epiphylla: Brazil, 1880, Puiggari 1086 (isotype).

Acta Chem. Scand. 24 (1970) No. 1 
Acknowledgements. I am indebted to Dr. Rolf Santesson, Institute of Systematic Botany, Uppsala, for the supply of identified lichen material and for valuable advice on lichenological matters. The costs of the investigation were defrayed by a grant from the Swedish Natural Science Research Council to Dr. Gerd Bendz at this Institute.

1. Santesson, R. Symbolae Botan. Upsalienses 12 (1952) 1.

2. Santesson, J. Acta Univ. Ups., Abstr. Upps. Diss. Sci. 127 (1969) 1.

3. Santesson, J. Arkiv Kemi 30 (1969) 363.

4. Santesson, J. Acta Chem. Scand. 21 (1967) 1162.

5. Bohman, G. Phytochemistry 8 (1969) 1829.

6. Santesson, J. To be published.

7. Bendz, G., Bohman, G. and Santesson, J. Acta Chem. Scand. 21 (1967) 2889.

8. Yosioka, I., Yamauchi, H., Morimoto, K. and Kitagawa, I. Tetrahedron Letters 1968 1149.

9. Bruun, T., Hollis, D. P. and Ryhage, R. Acta Chem. Scand. 19 (1965) 839.

10. Culberson, C. Chemical and Botanical Guide to Lichen Products, Univ. of N. Carolina Press, Chapel Hill 1969.

11. Santesson, J. Arkiv Kemi 31 (1969) 57.

12. Huneck, S. and Santesson, J. Z. Naturforsch. 24b (1969) 756.

13. Santesson, J. Phytochemistry 9 (1970). In press.

Received January 15, 1970.
The Single and Double Bonds

between $\boldsymbol{s p}^{2}$-Hybridized Carbon

Atoms, as Studied by the Gas

Electron Diffraction Method

\section{The Molecular Structure of Acrolein \\ MARIT TRAETEBERG}

\author{
Department of Chemistry, University of \\ Trondheim, NLHT, Trondheim, Norway
}

$T$ he molecular structure of acrolein is a natural choice for inclusion in the present research series. The molecular structure of this molecule was studied by microwave spectroscopy in $1966^{1}$ and more recently by electron diffraction. ${ }^{2}$ When the latter results appeared, however, the experimental part of the investigation reported here was already carried out, and it was decided to continue the structure study. Even if the structural results may be of somewhat reduced interest, it might be worth while to compare results obtained by different electron diffraction laboratories.

The experimental data for the electron diffraction study of acrolein were recorded at two camera distances, approximately $48 \mathrm{~cm}$ and $19 \mathrm{~cm}$. The data were combined to give an experimental molecular intensity function $(s M(s)$-function) in the $s$-range 1.25-45.0 $\AA^{-1}$. The molecular structure was studied by least squares refinements of the experimental molecular intensity function and by following the progress on radial distribution functions. In the structure analysis all $\mathrm{C}=\mathrm{C}-\mathrm{H}$ angles were assumed to be equal and the $\mathrm{CH}$ bond distance in the aldehyde group was assumed to be $0.02 \AA$ larger than the other $\mathrm{CH}$ bond distances.

Table 1 lists the final results for the internuclear distances and mean amplitudes of vibrations for acrolein. The distances are arranged in order of increasing internuclear distance so that it will be easy to identify them in Figs. 3 and 4 which show the experimental and theoretical radial distribution functions when two different damping constants are applied. The solid bars represent relative contributions from the internuclear distances listed in Table 1. 